\title{
Molecular variants of Grapevine rupestris stem pitting-associated virus infecting grapevines (Vitis spp.) in Brazil
}

\author{
Thor Vinícius Martins Fajardo ${ }^{1^{*}}$ \\ Aléxis Cardama Kin ${ }^{2}$ Osmar Nickel ${ }^{1}$
}

${ }^{1}$ Empresa Brasileira de Pesquisa Agropecuária (Embrapa Uva e Vinho), CP 130, 95701-008, Bento Gonçalves, RS, Brasil. E-mail: thor.fajardo@embrapa. br. "Corresponding author.

${ }^{2}$ Universidade Estadual do Rio Grande do Sul (UERGS), Bento Gonçalves, RS, Brasil.

\begin{abstract}
Grapevine rupestris stem pitting-associated virus (GRSPaV) is one of the most common viruses of grapevine. It is involved in the grafttransmissible disease rupestris stem pitting of the rugose wood complex. The objective of the research was to perform the molecular characterization of the coat protein (CP) gene of sixteen Brazilian GRSPaV isolates aiming to determine the occurrence of molecular variants (strains) of this virus. Nine grapevine samples were evaluated, from which dsRNA was extracted. Nucleotide sequences were generated by Next generation sequencing (NGS). Fifteen complete sequences of the GRSPaV CP gene were obtained and phylogenetically analyzed. Multiple alignments of the sequences showed identities of nucleotides ranging from $82 \%$ to $99 \%$, suggesting high variability among the CPs of Brazilian isolates. The study revealed that genetic variability of GRSPaV comprising three molecular variants is also present in Brazilian grapevine genotypes.

Key words: GRSPAV, Foveavirus, strains, lineages, genetic variability.
\end{abstract}

\author{
Variantes moleculares de Grapevine rupestris stem \\ pitting-associated virus infectando videiras (Vitis spp.) no Brasil
}

RESUMO: O GRSPaV é um dos vírus mais comuns da videira. Está associado à doença transmissível por enxertia denominada caneluras de rupestris que compõe o complexo do lenho rugoso. O objetivo do trabalho foi realizar a caracterização molecular do gene da proteina capsidial (CP) de 16 isolados brasileiros de GRSPaV visando determinar a ocorrência de variantes moleculares desse vírus. Nove amostras de videira foram avaliadas das quais foi extraído dsRNA. As sequências de nucleotídeos foram geradas pelo sequenciamento de nova geração (NGS). Quinze sequências completas do gene CP de GRSPaV foram obtidas e filogeneticamente analisadas. Os alinhamentos múltiplos entre as sequências mostraram identidades de nucleotideos variando de $82 \%$ a 99\%, sugerindo alta variabilidade entre as CPs de isolados brasileiros. O estudo revelou que a variabilidade genética de GRSPaV compreendendo três variantes moleculares também está presente nos genótipos de videira no Brasil.

Palavras-chave: GRSPaV, Foveavirus, estirpes, linhagens, variabilidade genética.

Among grapevine (Vitis spp.) pathogens, viruses stand out, considering that this crop is susceptible to numerous graft-transmissible agents that cause several diseases, reducing plant vigor, yield, productivity and also fruit quality. Grapevine rupestris stem pitting-associated virus (GRSPaV), genus Foveavirus, family Betaflexiviridae, is one of the most common viruses of grapevine and is widely distributed in many grape-growing areas of the world. GRSPaV is not mechanically transmissible and natural vectors are unknown. This virus is involved in the rugose wood complex as the agent of the disorder known as Rupestris stem pitting, and some of its strains have been shown to have a very close association with specific symptoms and disorders (BOUYAHIA et al., 2005). Since the characterization of GRSPaV in 1998, a number of studies have revealed the remarkable genetic variability of this virus, which may reflect the unclear pattern of its biological effects (MENG \& GONSALVES, 2007). At least, ten GRSPaV variants have been fully sequenced: GRSPaV (GenBank accession AF026278), RSPaV-1 (AF057136), -SG1 (AY881626), -BS (AY881627), -SY (AY368590), -PN (AY368172), -MG (FR691076), -PG (HE591388), -3138-07 (JX559646) and -GG (JQ922417) (HU et al., 2015). They are divided into four main groups depending on their complete genome sequences, and each group has the reference variant lineage (in bold) defined by NOLASCO et al. (2006) or MENG et al. (2006), respectively as follows: GRSPaVSY and VS (1 or IV), GRSPaV-SG1, MG and 3138- 
07 (2a or II), RSPaV-1, GRSPaV, GG and PG (2b or I) and GRSPaV-BS (3 or III) and an additional group GRSPaV-PN (V) (TERLIZZI et al, 2011). The positivesense, ssRNA of GRSPaV is $8.7 \mathrm{~kb}$ in length, and encodes five open reading frames (ORFs) in which the ORF in the 3' end encodes a $28 \mathrm{kDa}$ coat protein (CP) with 780bp (HU et al., 2015). Information about the variability of GRSPaV strains in Brazilian grapevines is very restricted (BASSO et al., 2010). Therefore, the aim of this research was to perform a molecular characterization of coat protein genes of GRSPaV to document the prevalence of molecular variants infecting Brazilian grapevines.

Nine genotypes were sampled (one sample/ genotype) in three grapevine collections in Rio Grande do Sul, São Paulo and Pernambuco States, Brazil. The evaluated $V$. vinifera plants were symptomatic, exhibiting foliar symptoms related to viruses and other genotypes were asymptomatic (Table 1). The GRSPaV $\mathrm{CP}$ isolates were characterized in enriched dsRNAs extracted from $30 \mathrm{~g}$ of bark scrapings per sample using CF11 cellulose. Sequencing data was generated from a complementary DNA library that was constructed by Macrogen (Korea) or Eurofins (USA). The Illumina HiSeq2000 platform was used to generate the pairedend reads. CLC Genomics Workbench software was used for quality trimming and de novo contig assembly from the reads. All contigs were analyzed using NCBI's Blast program (http://www.ncbi.nlm.nih.gov/ blast) against the viral RefSeq databases and also all contigs identified as GRSPaV were individually analyzed using Blastn against the GenBank database (FAJARDO et al., 2017).

Multiple sequence alignments of nucleotides (nt) and deduced amino acids (daa) were performed using ClustalX 2.1 and a pairwise

Table 1 - Information about sequences of GRSPaV included in study and available in GenBank.

\begin{tabular}{|c|c|c|c|c|c|}
\hline Country $^{*}$ & Genotypes & Isolate & $\begin{array}{l}\text { GenBank } \\
\text { accessions }\end{array}$ & $\begin{array}{l}\text { Nucleotide identity with } \\
\text { sequence variant }\end{array}$ & $\begin{array}{l}\text { Variant } \\
\text { lineage }\end{array}$ \\
\hline RS-Brazil & $V$. vinifera $\mathrm{cv}$. Cabernet Sauvignon & CS-BR & KT008367 & BS $(96 \%)$ & BS \\
\hline RS-Brazil & V. vinifera cv. Cabernet Sauvignon & VVCS2 & KT008368 & 3138-07 (96\%) & SG1 \\
\hline RS-Brazil & $V . f l e x u o s a$ & VF1 & KT008369 & BS $(97 \%)$ & BS \\
\hline RS-Brazil & $V$. flexuosa & VF2 & KT008370 & RSPaV-1 (99\%) & RSPaV-1 \\
\hline RS-Brazil & V. labrusca $\mathrm{cv}$. Isabel & VLIS1 & KT008371 & BS $(95 \%)$ & BS \\
\hline RS-Brazil & V. labrusca cv. Isabel & VLIS2 & KT008372 & BS $(92 \%)$ & BS \\
\hline SP-Brazil & V. labrusca cv. Isabel & VLIS3 & KT008373 & BS $(99 \%)$ & BS \\
\hline SP-Brazil & V. labrusca cv. Isabel & ISA-BR & KT008374 & RSPaV-1 (99\%) & RSPaV-1 \\
\hline SP-Brazil & $V$. gigas & VG & KT008375 & RSPaV-1 (99\%) & RSPaV-1 \\
\hline PE-Brazil & $V$. vinifera cv. Syrah & VVSY1 & KT008376 & BS $(95 \%)$ & BS \\
\hline PE-Brazil & $V$. vinifera cv. Syrah & VVSY2 & KT008377 & PG $(92 \%)$ & RSPaV-1 \\
\hline PE-Brazil & $V$. vinifera $\mathrm{cv}$. Tempranillo & TEMP-BR & KT008378 & $3138-07(96 \%)$ & SG1 \\
\hline RS-Brazil & $V$. vinifera $\mathrm{cv}$. Italia & VVIT & KT008379 & BS $(90 \%)$ & $?$ \\
\hline RS-Brazil & V. vinifera $\mathrm{cv}$. CG90450 & VVCG1 & KT008380 & BS $(96 \%)$ & $\mathrm{BS}$ \\
\hline RS-Brazil & V. vinifera $\mathrm{cv}$. CG90450 & VVCG2 & KT008381 & 3138-07 (90\%) & $?$ \\
\hline RS-Brazil & $V$. berlandierix $V$. rupestris cv. $110 \mathrm{R}$ & VN-BR & $\mathrm{KY} 321511 * *$ & PG $(99 \%)$ & --- \\
\hline USA & V. riparia & RSPaV-1 & NC_001948 & -- & $\mathrm{RSPaV}-1$ \\
\hline Italy & V.vinifera $\mathrm{cv}$. Moscato Giallo & GRSPaV-MG & FR691076 & -- & SG1 \\
\hline USA & V.vinifera cv. Syrah & GRSPaV-SY & AY368590 & -- & SY \\
\hline Canada & Vitis sp. cv. Bertille Seyve 5563 & GRSPaV-BS & AY881627 & -- & BS \\
\hline USA & Vitis vinifera cv. Pinot Noir & GRSPaV-PN & AY368172 & -- & $\mathrm{PN}$ \\
\hline USA & grapevine & GRSPaV & AF026278 & -- & RSPaV-1 \\
\hline USA & V. rupestris cv. St. George & GRSPaV-SG1 & AY881626 & -- & SG1 \\
\hline Canada & V. vinifera & $3138-07$ & JX559646 & -- & SG1 \\
\hline Italy & V. vinifera $c v$. Pinot Gris & PG & HE591388 & -- & RSPaV-1 \\
\hline USA & V. riparia $\mathrm{cv}$. Grande Glabre & GRSPaV-GG & JQ922417 & -- & RSPaV-1 \\
\hline Portugal & V. sylvestris & Vs279-2 & AY927684 & -- & SY \\
\hline USA & $V$. vinifera & GRSPaV-WA & KC427107 & -- & SG1 \\
\hline
\end{tabular}

"The Brazilian States of Rio Grande do Sul (RS), São Paulo (SP) and Pernambuco (PE), " partial CP gene and “?” not defined. 
nucleotide sequence identity matrix was generated using Sequence Demarcation Tool version 1.2 (SDT v1.2) (MUHIRE et al., 2014). The matrix generation of nt and daa identities were also performed using BioEdit v.7.2.5 software. The 15 sequences obtained in this research were aligned with 12 representative isolates of GRSPaV from the GenBank, which accession numbers of the nt sequences of the GRSPaV CPs used for phylogenetic analysis are presented in Table 1. Phylogenetic relationships were determined from the aligned sequences by using the neighborjoining (NJ) method using Kimura 2-parameter with gamma distribution $(\mathrm{G})$ and 2,000 bootstrap replications implemented in Molecular Evolutionary Genetics Analysis (MEGA 7.0.21) software package.

Twenty rooted rootstocks of grapevine cv. 110R (V. berlandieri x V. rupestris), not inoculated, exhibiting severe vein necrosis on leaves were sampled for total RNA extractions using the RNeasy Plant Mini kit (Qiagen) from 100mg of petioles of symptomatic leaves, grinding plant tissue in liquid nitrogen. Primer pairs used to amplify the partial CP of GRSPaV for one-step RT-PCR were 48V/49C (LIMA et al., 2006). The RT-PCR in a single step was carried out using One Step RT-PCR kit (Qiagen) and reactions were performed according to the manufacturer with $4 \mu \mathrm{L}$ of total RNA (ca. 400ng). The RT-PCR reactions and amplification cycling, amplified DNA analysis, elution of DNA fragments, cloning, purification of recombinant plasmids from Escherichia coli and nucleotide comparisons were performed as described by BASSO et al. (2010). The automatic nucleotide sequencing was performed with two clones.

Fifteen complete sequences of the GRSPaV CP gene (780 nt and 259 daa length) were obtained by NGS from nine different grapevine genotypes including wild and commercial cultivars of wine and table grapevines (Table 1). Fifteen CP sequences for Brazilian isolates of GRSPaV were deposited in GenBank under accession numbers KT008367 through KT008381 (Table 1). Multiple alignments between these sequences showed identities ranging from $82 \%$ to $99 \%$ (Figure 1A) and, $93 \%$ to $100 \%$, nt and daa; respectively, suggesting high variability among the CPs of Brazilian isolates.

The CP-based phylogenetic relationships of GRSPaV isolates from three Brazilian states were compared among themselves and with reference sequences from other grape growing regions. This analysis, using the NJ method, included a total of 15 $\mathrm{CP}$ sequences of local isolates of $\mathrm{GRSPaV}$ and 12 reference isolates (sequence variants) retrieved from the GenBank. Results showed segregation of 13 Brazilian GRSPaV CP sequences into three major lineages represented by the GRSPaV-BS, -SG1 and RSPaV-1 isolates (Table 1, Figure 1B). Only two studied isolates (VVIT and VVCG2) did not cluster in the previously defined groups (lineages) (Figure 1B); although, these isolates showed high nucleotide identities of $\mathrm{CP}$ gene with reference isolates of $\mathrm{GRSPaV}, 90 \%$ with $\mathrm{BS}$ and $90 \%$ with $3138-07$, respectively (Table 1). Each one of these lineages was assigned to a reference isolate to maintain a standardized nomenclature of GRSPaV sequence variant groups in analogy with a previous report by NOLASCO et al. (2006) and MENG et al. (2006). There have already been reports on the occurrence of sequence variants of GRSPaV in vineyards worldwide (LIMA et al., 2006).

$\mathrm{GRSPaV}$ is implicated in the rupestris stem pitting disease of the rugose wood complex responsible for graft incompatibility, delayed bud burst, severe decline, stem pitting, and even death of vines. This virus has been demonstrated to comprise a family of molecular variants, and a specific relationship between some of the viral variant groups and distinct Vitis species appears to exist. It seems that the RSPaV-1 and GRSPaV-SG1 lineages are more prevalent, whereas the GRSPaV-BS and GRSPaV-VS (SY) lineages are less common (MENG \& GONSALVES, 2007). These authors also mentioned that viral variants that are distinct from these four variant groups (lineages) may exist in nature, and that additional distinct variants may be discovered later on.

From grapevines cv. 110R, exhibiting vein necrosis, it was possible to amplify a DNA fragment (330bp) (GenBank KY321511) with 100\% nt identity between this and the CF210 (EF690384) Brazilian isolate and $99 \%$ with PG isolate (Table 1). Some information about biological properties associated with molecular variants of $\mathrm{GRSPaV}$ is available such as decline and incompatibility problems associated with GRSPaV-SY (AY368590) (LIMA et al., 2006).

Reliable and comprehensive detection and phylogenetic analysis of molecular variants of GRSPaV infecting grapevines were achieved after applying NGS and conventional RT-PCR. This result contributes to the improvement of the viral diagnosis, since it expands the knowledge on the genetic variability of $\mathrm{GRSPaV}$ in Brazil at the level of sequence variants. It is necessary to extend this study to sample productive Brazilian vineyards aiming to determine the incidence of representative variants in Brazilian grape growing areas. This study revealed that genetic variability of GRSPaV is also present in Brazilian grapevine genotypes and the information should be taken into consideration in symptomatological assessments and biological and molecular indexing. 

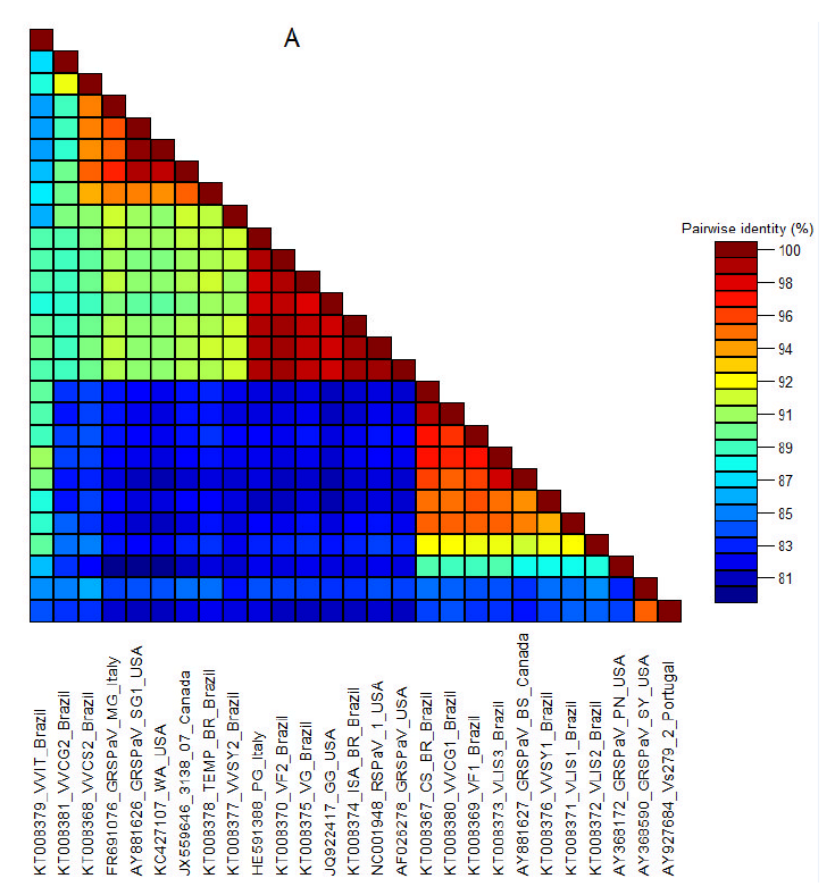

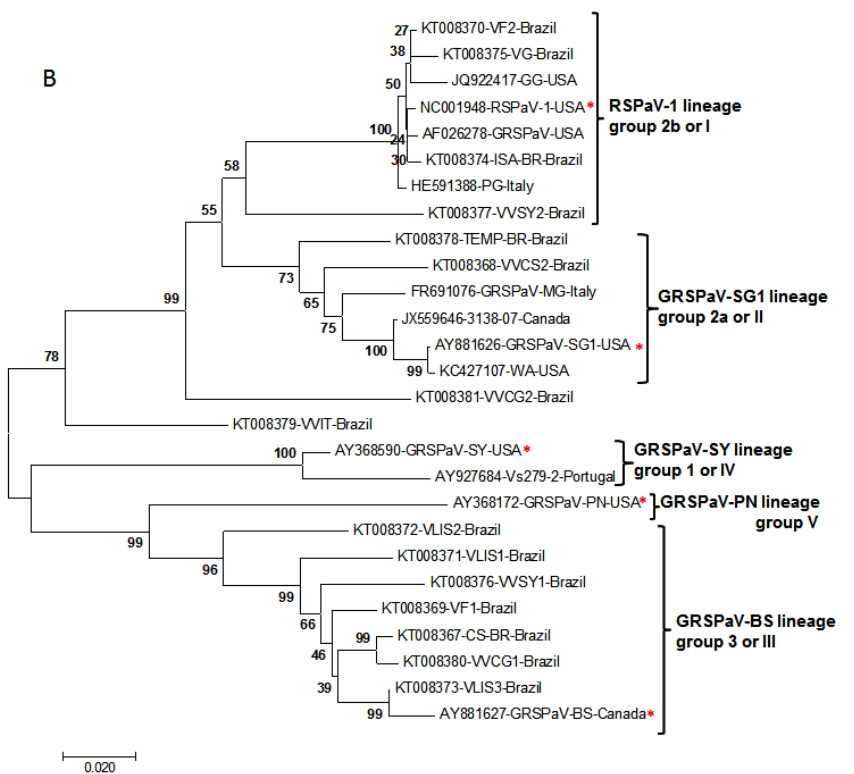

Figure 1 - A. Pairwise nucleotide sequence identity matrix of $15 \mathrm{GRSPaV}$ isolates from Brazil and 12 representative isolates from the GenBank, generated using SDT software. B. Phylogenetic relationship among GRSPaV isolates based on the multiple alignment of the complete coat protein gene nucleotide sequences of 15 isolates from Brazil and other 12 isolates and sequence variants retrieved from the GenBank. The tree was constructed by the neighborjoining method using Kimura 2-parameter with gamma distribution $(\mathrm{G})$ and 2,000 bootstrap replications implemented using MEGA 7.0.21 software package. Names of GRSPaV isolates and origins were included according to the GenBank. Reference variants for each lineage are marked with an asterisk and specific clusters (groups) are indicated as defined by NOLASCO et al. (2006) or MENG et al. (2006). Bar: number of nucleotide substitutions per site. 


\section{ACKNOWLEDGEMENTS}

To Empresa Brasileira de Pesquisa Agropecuária (Embrapa) for the financial support to this research (Project 02.13.14.002) and Fundação de Amparo a Pesquisa do Estado do Rio Grande do Sul (FAPERGS) for the student scholarship. To Tatsuya Nagata (UnB, Brazil) and Maher Al Rwahnih (FPS, UC Davis, USA) for their help with bioinformatic analysis of NGS.

\section{REFERENCES}

BASSO, M.F. et al. Molecular detection and identification of virus associated with symptomatic and symptomless grapevines. Ciência Rural, v.40, p.2249-2255, 2010. Available from: <http://dx.doi. org/10.1590/S0103-84782010001100001>. Accessed: June 26, 2017.

BOUYAHIA, H. et al. Grapevine rupestris stem pitting-associated virus is linked with grapevine vein necrosis. Vitis, v.44, p.133-137, 2005. Available from: <http://ojs.openagrar.de/index.php/VITIS/ article/view/4322>. Accessed: June 26, 2017.

FAJARDO, T.V.M. et al. High-throughput sequencing applied for the identification of viruses infecting grapevines in Brazil and genetic variability analysis. Tropical Plant Pathology, 2017. Available from: <http://link.springer.com/article/10.1007/s40858-017-01428>. Accessed: June 26, 2017. doi: 10.1007/s40858-017-0142-8.

HU, G.-J. et al. Molecular characterizations of two grapevine rupestris stem pitting-associated virus isolates from China. Archives of Virology, v.160, p.2641-2645, 2015. Available from: $<$ http://link.springer.com/article/10.1007/s00705-015-2544-6>. Accessed: June 26, 2017.

LIMA, M.F. et al. Molecular analysis of a California strain of Rupestris stem pitting-associated virus isolated from declining
Syrah grapevines. Archives of Virology, v.151, p.1889-1894, 2006. Available from: <http://link.springer.com/article/10.1007/ s00705-006-0742-y>. Accessed: Jun. 26, 2017.

MENG, B. et al. Genetic diversity analyses of grapevine Rupestris stem pitting-associated virus reveal distinct population structures in scion versus rootstock varieties. Journal of General Virology, v.87, p.1725-1733, 2006. Available from: <http:// jgv.microbiologyresearch.org/content/journal/jgv/10.1099/ vir.0.81533-0>. Accessed: June 26, 2017.

MENG, B., GONSALVES, D. Grapevine rupestris stem pittingassociated virus: A decade of research and future perspectives. Plant Viruses, v.1, n.1, p.52-62, 2007. Available from: $<$ http://www.globalsciencebooks.info/Online/GSBOnline/ images/0706/PV_1(1)/PV_1(1)52-62o.pdf $>$. Accessed: June 26, 2017.

MUHIRE, B.M. et al. SDT: A virus classification tool based on pairwise sequence alignment and identity calculation. PLOS ONE, v.9, e108277, 2014. Available from: <http://journals. plos.org/plosone/article?id=10.1371/journal.pone.0108277>. Accessed: June 26, 2017.

NOLASCO, G. et al. Rupestris stem pitting associated virus isolates are composed by mixtures of genomic variants which share a highly conserved coat protein. Archives of Virology, v.151, p.83-96, 2006. Available from: <http://link.springer.com/ article/10.1007/s00705-005-0611-0>. Accessed: June 26, 2017.

TERLIZZI et al. Detection of multiple sequence variants of Grapevine rupestris stem pitting-associated virus using primers targeting the polymerase domain and partial genome sequencing of a novel variant. Annals of Applied Biology, v.159, p.478-490, 2011. Avalilable from: <http://dx.doi.or g/10.1111/j.1744-7348.2011.00512.x>. Accessed: Sep. 18, 2017. 